\title{
Physico-chemical characteristics of copper tailings and pyrite soils in Western Uganda: Implication for phytoremediation
}

\author{
Jamilu Edirisa Ssenku ${ }^{1}{ }^{*}$, Muhammad Ntale ${ }^{2}$, Hannington Oryem Origa ${ }^{1}$ \\ ${ }^{1}$ Department of Biological Sciences, College of Natural Sciences, Makerere University, Kampala, Uganda \\ ${ }^{2}$ Department of Chemistry, College of Natural Sciences, Makerere University, Kampala, Uganda
}

Email address:

jssenku@gmail.com (J. E. Ssenku)

\section{To cite this article:}

Jamilu Edirisa Ssenku, Muhammad Ntale, Hannington Oryem Origa. Physico-Chemical Characteristics of Copper Tailings and Pyrite Soils in Western Uganda: Implication for Phytoremediation. International Journal of Environmental Monitoring and Analysis.

Vol. 2, No. 4, 2014, pp. 191-198. doi: 10.11648/j.ijema.20140204.12

\begin{abstract}
Generation of enormous volume of wastes from mining activities that pollute the surrounding environment is still a global challenge. Pollution emanating from the wastes usually leads to loss of vegetation cover whose re-establishment through phytoremediation requires an assemblage of the physico-chemical data of the soils on which designing of remediation strategies are based. Thus, the physico-chemical characterisation of the tailings and pyrite soils was conducted following standard procedures and their variation across depths, seasons and earmarked zones evaluated. Both copper tailings and pyrite soils were extremely acidic, deficient in total nitrogen and available phosphorous and heavily polluted with $\mathrm{Cu}, \mathrm{Co}$ and Ni relative to the unpolluted soils. The distribution of available P, total nitrogen and heavy metals was heterogenous varying significantly across zones, depths and not significantly across seasons except available phosphorous. Re-adjustment of the physico-chemical parameters to levels that permit seedling establishment and growth through application of amendment materials is a pre-requisite for any successful phytoremediation. Evenness in their application may be hard to achieve leading to emergence of red spots hence a need for close monitoring during the phytoremediation programme.
\end{abstract}

Keywords: Physico-Chemical, Copper Tailings, Pyrite Trail, Tailings Dams, Phytoremediation

\section{Introduction}

Mining activities generate wastes which are usually deposited on the surface and abandoned after definitive closure of the mines. Due to pollution by the wastes the soils close to them are usually degraded to magnitudes that lead to complete loss of vegetation cover, land use and impediment of revegetation for a long period of time. Heavy metal pollution of the lithosphere and hydrosphere ecosystems by abandoned mine wastes is still a global challenge as the wastes from which it arises are generated in large quantities and have a long-term persistence in the environment. There are numerous sources of heavy metals that pollute the environment but mining has produced a significant legacy of polluted and degraded soils [1]. Despite the existence of numerous conventional techniques that can be applied, remediation of such metal polluted soils is still a difficult task [2]. Phytoremediation technique that involves using plants and soil microbes for the removal and cleaning of pollutants from the soil including heavy metals [3], is a potentially effective technology applicable to restoration of contaminated soils [4]. The technique requires assemblage of baseline data on physico-chemical status of the polluted site before application.

Near Queen Elizabeth Conservation Area (QECA) enormous volumes of pyrite materials to the tune of 1.13 million metric tonnes were dumped from 1956 to 1982 to form a large cobaltiferous stockpile [5]. Concurrently flotation tailings to the tune of 15 million metric tonnes were dumped in various areas in Kilembe valley in which the fast flowing River Nyamwamba is located [6]. The tailings dams and the cobaltiferous stockpile have remained devoid of vegetation since suspension of mining activities in 1982 leading to wide dispersal of pyrite materials laden withheavy metals into gardens and surrounding aquifers at Kilembe and into QECA to form the largely bare pyrite trail. Establishment of the physico-chemical status of the mine 
wastes polluted site to be remediated through phytoremediation is very crucial at the time of designing methodologies to be applied. Given the long time history of redistribution of the pollutants, we hypothesized that the physico-chemical parameters of copper tailings and pyrite soils were homogeneously distributed in the entire site.

In spite of previous studies carried out in the area, no comprehensive geochemical data is available upon which remediation strategies can be based. Studies conducted in the area by Oryem-Origa et al. [5] focussed on determination of total concentration of heavy metals yet it has presumably low biological significance because such concentrations provide very limited information on the mobility and bioavailability of the elements [7]. Again no work has been done to establish nutritional status of the soil with respect to total nitrogen, organic matter content and available phosphorous, yet they are important nutrients necessary for growth of plants in a phytoremediation process. In anticipation of utilising deep rooted plants in phytoremediation, geochemical data of the entire site and its spatial and temporal variations had to be established as it could not be traced anywhere in the literature bases of the site. Therefore in this study we carried out a comprehensive physicochemical characterization of the mine waste polluted soils with the salient aim of establishing baseline data on which current studies were based and one that could subsequently be based on to design remediation strategies of the area through phytoremediation. Furthermore the contamination levels of the heavy metals were determined in reference to their available concentrations in the unpolluted soils.

\section{Materials and Methods}

\subsection{Study Area}

The study area comprised of the pyrite trail in Queen Elizabeth Conservation Area (QECA) and the copper tailings dams in the vicinity of Kilembe Town area. It is located within the geographical coordinates and at elevations shown in Table 1. The area has a tropical climate with rainfall which is bi-modally distributed with the wetter periods occurring from March to May and August to November. The area receives an average rainfall ranging between $900-1600 \mathrm{~mm}$ annually. The pyrite trail zones were characterised with mean minimum temperature of $18.5{ }^{\circ} \mathrm{C}$ and a mean maximum temperature of $30.8^{\circ} \mathrm{C}$. Records of temperatures for the Kilembe tailings dams were not available, but being located at higher altitude it was always cooler than the pyrite trail site. During dry seasons salts of heavy metals of varying colours crystallize out to cover soils (Figure 1). It was drained by a major drainage channel through which large volumes of wastes were loaded into the area and a minor drainage channel.

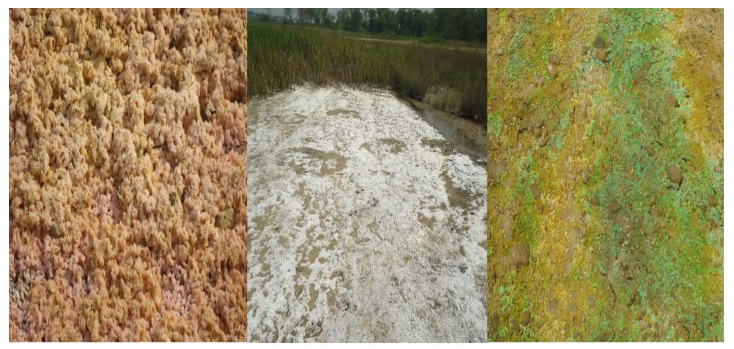

Figure 1. Crystals of heavy metals of varying colours covering pyrite soil surfaces during the dry season.

Table 1. Geographical location of the zones within the study area

\begin{tabular}{lllll}
\hline Area & Zone & Latitude & Longitude & Elevation (M) \\
\hline Kilembe tailings dams & KTDZ & $0^{\circ} 11^{\prime} 16.12^{\prime \prime N}$ & $30^{\circ} 01^{\prime} 11.43 " \mathrm{E}$ & 1243 \\
Pyrite trail & PTZA & $0^{\circ} 08^{\prime} 55.18 " \mathrm{~N}$ & $30^{\circ} 04^{\prime} 28.87^{\prime \prime} \mathrm{E}$ & 937 \\
Pyrite trail & PTZB & $0^{\circ} 08^{\prime} 44.08^{\prime \prime} \mathrm{N}$ & $30^{\circ} 04^{\prime} 39.86^{\prime \prime} \mathrm{E}$ & 925 \\
Convergence area & PTZC & $0^{\circ} 08^{\prime} 37.74 " \mathrm{~N}$ & $30^{\circ} 04^{\prime} 37.77^{\prime \prime} \mathrm{E}$ & 932 \\
Pyrite trail & PTZD & $0^{\circ} 08^{\prime} 50.16^{\prime \prime} \mathrm{N}$ & $30^{\circ} 04^{\prime} 26.16^{\prime \prime} \mathrm{E}$ & 935 \\
Pyrite trail & PTZE & $0^{\circ} 08^{\prime} 46.94 " \mathrm{~N}$ & $30^{\circ} 04^{\prime} 29.91^{\prime \prime} \mathrm{E}$ & 928 \\
Pyrite trail & PTZF & $0^{\circ} 08^{\prime} 43.35 " \mathrm{~N}$ & $30^{\circ} 04^{\prime} 34.75^{\prime \prime} \mathrm{E}$ & 927 \\
Unpolluted & $\mathrm{UPZ}$ & $0^{\circ} 08^{\prime} 41.48^{\prime \prime} \mathrm{N}$ & $30^{\circ} 04^{\prime} 25.71^{\prime \prime} \mathrm{E}$ & 933 \\
\hline
\end{tabular}

\subsection{Study Design}

The study area was majorly divided into four areas that comprised of Kilembe Tailings Dams, the main and minor channels drained pyrite trail areas, convergence area (where polluted storm water from the main and minor channel converges) and the unpolluted area. The tailings dams, the unpolluted area and convergence area each constituted a zone coded as KTDZ (Kilembe Tailings Dams Zone), UNPZ (Unpolluted Zone) and PTZC (Pyrite trail zone of convergence) respectively. Three zones coded as PTZA (Pyrite Trail Zone A), PTZB (Pyrite Trail Zone B) and PTZF (Pyrite Trail Zone F) and two coded as PTZD (Pyrite
Trail Zone D) and PTZE (Pyrite Trail Zone E) were earmarked down slope along the main and minor drainage channel areas respectively. For future reference the geographical coordinates of each zone was determined with a GPS.

\subsection{Sampling Strategy}

The copper tailings and pyrites soil samples from KTDZ and pyrite trail zones respectively, were collected in triplicates from randomly selected spots in each zone at the depths of 0-30 cm (Top layer), 30-60 cm (Middle layer), and 60-90 cm (Bottom layer) during the dry and wet season using a soil auger. A homogenized soil sample from each 
depth for a particular replicate was prepared and packed in a well labelled polythene bag. For comparison purposes, unpolluted soil samples were collected from the top layer only. Samples for determination of the background available concentrations of heavy metals $(n=10)$ were picked from the top layer in the unpolluted area. The samples were later taken to the laboratory for physico-chemical characterization.

\subsection{Physico-Chemical Characterization of Soil Samples}

Physico-chemical characterisation of the soils samples was done at National Agricultural Research Laboratories (NARL) at Kawanda following standard procedures. Soil $\mathrm{pH}$ (soil: deionised water $=1: 2.5 \mathrm{w} / \mathrm{v}$ ) was determined using a calibrated $\mathrm{pH}$ meter, organic matter content by Walkley-Black potassium dichromate wet oxidation [8] as described by [9] and total nitrogen was determined by the semi-micro Kjeldahl method [10]. Extraction of available phosphorous and heavy metals was done using Mehlich 3 extractant. In brief, the soil sample was dried in an oven at $45^{\circ} \mathrm{C}$ for 48 hours. The dried sample was pulverized to pass hrough a $2 \mathrm{~mm}$ sieve to remove any coarse particles. The sample was then sub-sampled to a very fine powder in a mortar. The dry sample $(3 \mathrm{~g})$ was weighed into a $50 \mathrm{ml}$ centrifuge vial and $30 \mathrm{ml}$ of Melich 3 extractant was added. The mixture was then shaken at $200 \mathrm{rpm}$ for 5 minutes and later left to stand for 10 minutes for settling before centrifuging at $2000 \mathrm{rpm}$ for 5 minutes. The available phosphorus in the extract was determined following Ammonium Molybdate-Ascorbic acid method [11] using a $\mathrm{UV} /$ Visible spectrophotometer at $860 \mathrm{~nm}$. The heavy metal concentrations representing largely available concentrations for plant uptake was determined with an atomic absorption spectrophotometer (SHIMADZU AA-6800).
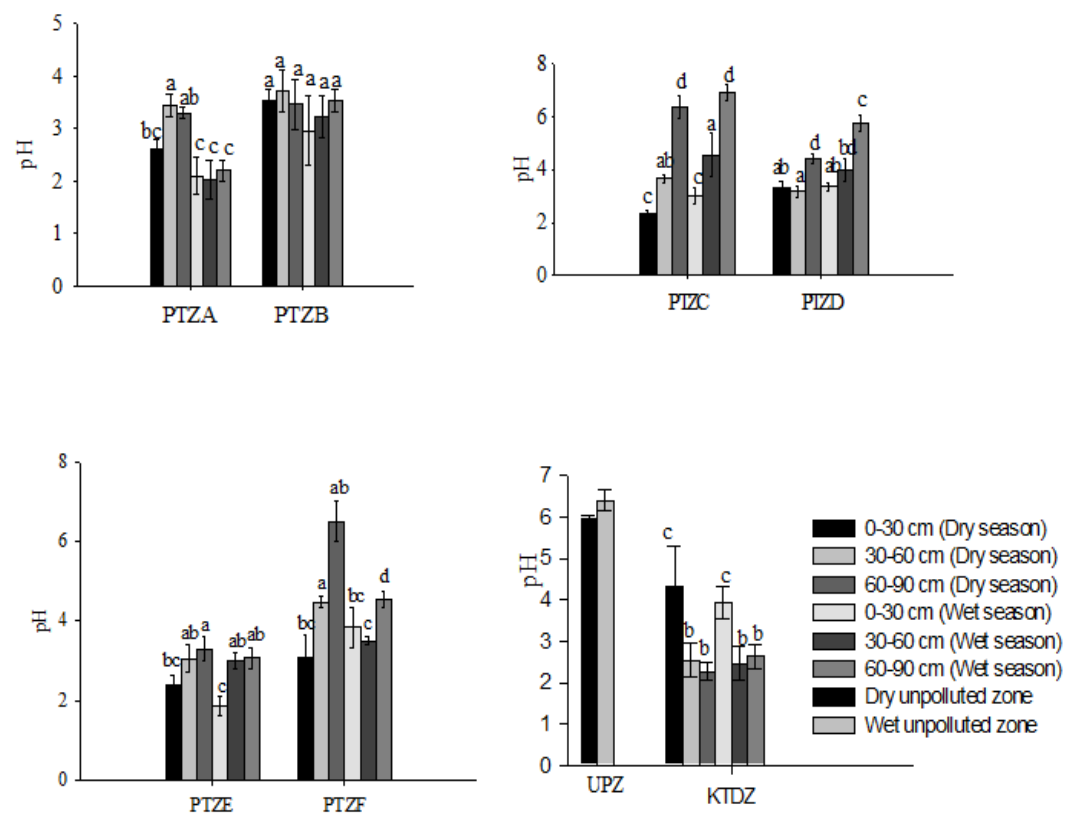

Figure 2. Mean $\mathrm{pH}( \pm S E M, n=3)$ variation across zones, season and depth for pyrite soils and copper tailings. Bars followed by different letters for particular zones are significantly different (Tukey's HSD test, $p<0.05$ ).

\subsection{Heavy Metal Contamination Status of Copper Tailings And Pyrite Soils}

The heavy metal contamination status of the copper tailings and pyrite soils was assessed by determining the contamination factor (CF) using the expression below:

$$
C F=\frac{C_{\text {metal }}}{C_{\text {background }}}
$$

Where $C_{\text {metal }}$ is the available heavy metal concentration of copper tailings or pyrite soils and $C_{\text {background }}$ is the mean available heavy metal concentration of the unpolluted soils. The mean available $(n=10)$ geochemical background values of unpolluted soils determined in this study $(\mathrm{Cu}=5.97$, $\mathrm{Co}=4.02, \mathrm{Ni}=2.08$, and $\mathrm{Pb}=0.21$ ) were used. The $C F<1$ referred to low contamination; $1 \leq C F<3$ indicates moderate contamination; $3 \leq C F \leq 6$ means considerable (High) contamination $C F>6$ referring to very high contamination $[12,13,14]$.

\subsection{Statistical Analysis}

All analyses were performed using $\mathrm{R}$ statistical package 2.13.2 [15] and STATA 9.0. Prior to any statistical analysis, data distributions were checked for normality and homogeneity of variances. Data that were heteroscedastic and/or with strong deviations from normality were log-transformed. Variability in means among parameters was analyzed with analysis of variance (two way ANOVA) followed by a post-hoc test (Tukey's Honest Significant Multiple Comparison) with means considered to be significantly different at $\mathrm{p}<0.05$. 


\section{Results}

\section{1. pH of Copper Tailings and Pyrite Soils}

Copper tailings and pyrite soils were acidic in nature with extremely low $\mathrm{pH}$ ranges. The $\mathrm{pH}$ of copper tailings at KTDZ ranged between 2.27 $\pm 0.37-3.43 \pm 0.21$ (Figure 2). For pyrite soils, it was ranging between $1.87 \pm 0.25$ $6.50 \pm 0.50$ at PTZE. Pyrite soils from PTZC, PTZD and PTZF at the depth of $60-90 \mathrm{~cm}$ had significantly higher $\mathrm{pH}$ than pyrite soils from the upper layers (Turke'ys HSD test, $\mathrm{p}<0.05$ ). $\mathrm{pH}$ significantly varied across zones (ANOVA, $F=11.85, \mathrm{df}=6, \mathrm{p}=0.0001$, depth $(F=19.93, \mathrm{df}=2, \mathrm{p}=0.0001$ and zone $(F=5.13, \mathrm{df}=1, \mathrm{p}=0.026)$.

\subsection{Organic Matter, Total Nitrogen and Available Phosphorous Distribution}

The mean values of organic matter, total nitrogen and available phosphorous are presented in Table 2. Results showed a significantly lower organic matter content, total nitrogen and available phosphorous as compared to the unpolluted soils. The organic matter content varied significantly across zones and depth $(F=41.68, \mathrm{df}=6$, $\mathrm{p}<0.0001)$ and $(F=24.0, \mathrm{df}=2, \mathrm{p}<0.0001)$ respectively but did not vary significantly across seasons. The distribution pattern of organic matter with depth was heterogeneous, with the 30-60 cm depth having significantly higher content than 0-30 and 60-90 cm depths at PTZA, PTZC, PTZE, and PTZF (Tukey's HSD, p<0.05) contrary to KTDZ and PTZB where the content was relatively higher at the top layer than the mid and bottom layers.

Total nitrogen variation across depth and zones was significant $(F=10.36, \mathrm{df}=2, \mathrm{p}<0.001)$ and $(F=4.4, \mathrm{df}=6$, $\mathrm{p}<0.001)$ while seasonal variations were not significant. Available phosphorous varied significantly across zones, depths and seasons $(F=21.90, \mathrm{df}=6, \mathrm{p}<0.001),(F=29.94$, $\mathrm{df}=2, \mathrm{p}<0.001)$ and $(F=37.31, \mathrm{df}=1, \mathrm{p}<0.01)$ respectively. With the exception of PTZC in the dry season, available phosphorous was significantly higher in the middle layer of copper tailings and pyrite soils for both dry and wet seasons than in the top and middle layers (Tukey's HSD, $p<0.05$ ).

Table 2. The mean values ( \pm SEM, $n=3)$ of organic matter content, total nitrogen and available phosphorous for copper tailings and pyrite soils, from the different zones and depths for dry and wet seasons

\begin{tabular}{|c|c|c|c|c|c|c|}
\hline \multirow{2}{*}{$\begin{array}{l}\text { Zone/depth } \\
\text { KTDZ }\end{array}$} & \multicolumn{2}{|c|}{ Organic matter (\% DW) } & \multicolumn{2}{|c|}{ Total N (\% DW) } & \multicolumn{2}{|c|}{ Available P (mg/kg DW) } \\
\hline & Dry & Wet & Dry & Wet & Dry & Wet \\
\hline $0-30$ & $4.49 \pm 0.18 b$ & $5.55 \pm 0.53 \mathrm{e}$ & $0.16 \pm 0.03 a$ & $0.16 \pm 0.01 \mathrm{a}$ & $7.45 \pm 0.43 b$ & $4.24 \pm 0.20 \mathrm{bc}$ \\
\hline $30-60$ & $1.38 \pm 0.13 \mathrm{a}$ & $2.29 \pm 0.34 d$ & $0.15 \pm 0.04 \mathrm{a}$ & $0.15 \pm 0.03 a$ & $21.73 \pm 1.38 \mathrm{a}$ & $14.49 \pm 3.04 \mathrm{~d}$ \\
\hline $60-90$ & $0.63 \pm 0.05 \mathrm{ac}$ & $0.39 \pm 0.19 \mathrm{c}$ & $0.12 \pm 0.02 \mathrm{a}$ & $0.13 \pm 0.01 \mathrm{a}$ & $2.97 \pm 0.15 \mathrm{c}$ & $5.44 \pm 0.69 b c$ \\
\hline \multicolumn{7}{|l|}{ PTZA } \\
\hline $0-30$ & $2.81 \pm 0.50 \mathrm{bc}$ & $1.76 \pm 0.86 b$ & $0.16 \pm 0.03 b$ & $0.15 \pm 0.01 b$ & $2.01 \pm 0.17 b$ & $4.92 \pm 0.30 \mathrm{~b}$ \\
\hline $30-60$ & $8.39 \pm 0.47 \mathrm{a}$ & $9.71 \pm 0.05 \mathrm{~d}$ & $0.29 \pm 0.06 \mathrm{a}$ & $0.23 \pm 0.01 \mathrm{ab}$ & $16.14 \pm 3.95 \mathrm{a}$ & $17.18 \pm 0.93 \mathrm{a}$ \\
\hline $60-90$ & $3.50 \pm 0.42 \mathrm{c}$ & $3.26 \pm 0.14 \mathrm{c}$ & $0.28 \pm 0.01 \mathrm{c}$ & $0.18 \pm 0.01 b$ & $3.23 \pm 0.52 b$ & $25.14 \pm 1.30 \mathrm{c}$ \\
\hline \multicolumn{7}{|l|}{ PTZB } \\
\hline $0-30$ & $3.82 \pm 0.97 \mathrm{ab}$ & $4.98 \pm 0.73 b$ & $0.14 \pm 0.04 b c$ & $0.14 \pm 0.05 \mathrm{ac}$ & $4.82 \pm 0.86 \mathrm{bc}$ & $3.30 \pm 0.71 \mathrm{c}$ \\
\hline $30-60$ & $3.79 \pm 1.11 \mathrm{bc}$ & $2.27 \pm 0.25 \mathrm{acd}$ & $0.22 \pm 0.04 \mathrm{ab}$ & $0.23 \pm 0.17 \mathrm{ab}$ & $32.30 \pm 8.38 \mathrm{a}$ & $50.37 \pm 5.34 d$ \\
\hline $60-90$ & $1.59 \pm 0.45 \mathrm{~d}$ & $1.79 \pm 0.10 \mathrm{~cd}$ & $0.12 \pm 0.01 \mathrm{c}$ & $0.24 \pm 0.06 \mathrm{~b}$ & $12.61 \pm 4.89 b$ & $14.76 \pm 2.96 b$ \\
\hline \multicolumn{7}{|l|}{ PTZC } \\
\hline $0-30$ & $3.26 \pm 0.12 \mathrm{ab}$ & $4.31 \pm 0.59 b$ & $0.17 \pm 0.03 \mathrm{a}$ & $0.14 \pm 0.02 \mathrm{c}$ & $3.32 \pm 0.44 \mathrm{c}$ & $12.15 \pm 0.61 \mathrm{c}$ \\
\hline $30-60$ & $5.73 \pm 0.58 \mathrm{c}$ & $6.82 \pm 0.70 \mathrm{c}$ & $0.28 \pm 0.04 b$ & $0.29 \pm 0.05 b$ & $84.14 \pm 2.89 \mathrm{ab}$ & $42.60 \pm 9.55 \mathrm{~d}$ \\
\hline $60-90$ & $0.89 \pm 0.18 \mathrm{~d}$ & $2.49 \pm 0.24 \mathrm{a}$ & $0.08 \pm 0.02 c$ & $0.18 \pm 0.01 \mathrm{c}$ & $81.98 \pm 8.23 a$ & $95.20 \pm 10.40 \mathrm{~b}$ \\
\hline \multicolumn{7}{|l|}{ PTZD } \\
\hline $0-30$ & $3.39 \pm 0.35 b$ & $1.95 \pm 0.39 \mathrm{c}$ & $0.19 \pm 0.04 \mathrm{a}$ & $0.13 \pm 0.01 \mathrm{a}$ & $7.00 \pm 0.47 \mathrm{a}$ & $6.53 \pm 2.86 a$ \\
\hline $30-60$ & $4.69 \pm 0.30 \mathrm{a}$ & $3.91 \pm 0.31 \mathrm{ab}$ & $0.21 \pm 0.03 \mathrm{a}$ & $0.19 \pm 0.01 \mathrm{a}$ & $22.51 \pm 2.00 \mathrm{ab}$ & $67.49 \pm 11.58 \mathrm{~d}$ \\
\hline $60-90$ & $2.37 \pm 0.23 \mathrm{a}$ & $2.52 \pm 0.25 \mathrm{c}$ & $0.16 \pm 0.05 a$ & $0.18 \pm 0.05 a$ & $39.98 \pm 2.67 b$ & $86.44 \pm 13.53 \mathrm{c}$ \\
\hline \multicolumn{7}{|l|}{ PTZE } \\
\hline $0-30$ & $2.80 \pm 0.60 b c$ & $2.99 \pm 0.27 \mathrm{c}$ & $0.15 \pm 0.02 b$ & $0.14 \pm 0.01 b$ & $4.49 \pm 0.50 b$ & $9.92 \pm 1.17 \mathrm{ae}$ \\
\hline $30-60$ & $5.16 \pm 0.29 a$ & $9.29 \pm 0.66 \mathrm{~d}$ & $0.23 \pm 0.07 \mathrm{a}$ & $0.25 \pm 0.02 \mathrm{a}$ & $10.49 \pm 1.00 \mathrm{a}$ & $38.54 \pm 3.03 d$ \\
\hline $60-90$ & $2.45 \pm 0.35 c$ & $4.01 \pm 0.62 \mathrm{c}$ & $0.21 \pm 0.01 \mathrm{ba}$ & $0.18 \pm 0.02 \mathrm{ab}$ & $5.98 \pm 0.22 b c$ & $28.58 \pm 1.63 \mathrm{c}$ \\
\hline \multicolumn{7}{|l|}{ PTZF } \\
\hline $0-30$ & $0.39 \pm 0.04 b$ & $2.27 \pm 0.12 \mathrm{ab}$ & $0.07 \pm 0.00 \mathrm{a}$ & $0.27 \pm 0.08 b$ & $6.99 \pm 0.61 b$ & $32.67 \pm 1.83 \mathrm{e}$ \\
\hline $30-60$ & $4.14 \pm 2.24 a$ & $4.91 \pm 0.69 a$ & $0.19 \pm 0.00 \mathrm{ab}$ & $0.19 \pm 0.02 \mathrm{ab}$ & $26.76 \pm 1.28 \mathrm{a}$ & $59.53 \pm 2.05 d$ \\
\hline $60-90$ & $2.83 \pm 0.04 \mathrm{ab}$ & $2.87 \pm 0.79 \mathrm{ab}$ & $0.17 \pm 0.01 \mathrm{ab}$ & $0.16 \pm 0.02 \mathrm{ab}$ & $11.13 \pm 0.48 b$ & $43.01 \pm 2.94 \mathrm{c}$ \\
\hline \multicolumn{7}{|l|}{ UPZ } \\
\hline $0-30$ & $9.30 \pm 0.56$ & $10.36 \pm 1.80$ & $0.45 \pm 0.01$ & $0.46 \pm 0.04$ & $76.31 \pm 3.64$ & $83.23 \pm 2.65$ \\
\hline
\end{tabular}

Means with different letters within the columns for dry and wet seasons for a particular zone are significantly different; Tukey’s HSD test, (p <.05).

\subsection{Distribution of Available Heavy Metals}

Results of available heavy metal concentrations and their distribution are presented in Table 3. The copper tailings and pyrite soils were characterised by significantly higher available concentrations of heavy metals than in the unpolluted soils (Tukey's HSD test, $\mathrm{p}<0.05$ ). The available concentrations of $\mathrm{Cu}, \mathrm{Co}$, and $\mathrm{Ni}$ in the top layer of the copper tailings at KTDS was significantly lower than that of 
the middle and bottom layers (Tukey's, $\mathrm{p}<0.05$ ). Below the top layer, their concentrations sharply increased but had narrower depth variations. In majority of the zones, the concentrations of the heavy metals in the top layer for the dry season was significantly higher than that of the wet season (Tukey's test, $\mathrm{p}<0.05$ ). The distribution of $\mathrm{Cu}, \mathrm{Co}, \mathrm{Ni}$ and $\mathrm{Pb}$ was heterogeneous varying significantly across zones $(F=26.36, \mathrm{df}=6, \mathrm{p}<0.001),(F=19.39, \mathrm{df}=6, \mathrm{p}<0.01)$, $(F=10.72, \mathrm{df}=6, \mathrm{p}<0.01)$ and $(F=16.21, \mathrm{df}=6, \mathrm{p}<0.01)$ respectively. Overall, seasonal variations for $\mathrm{Cu}, \mathrm{Co}, \mathrm{Ni}$ and $\mathrm{Pb}$ were not significant while the one due to depth was only significant for $\mathrm{Co}, \mathrm{Ni}$ and $\mathrm{Pb}(F=14.44, \mathrm{df}=2, \mathrm{p}<0.01)$, $(F=16.00, \mathrm{df}=2, \mathrm{p}<0.01)$ and $(F=31.22, \mathrm{df}=2, \mathrm{p}<0.01)$ respectively but not significant for $\mathrm{Cu}(F=0.97, \mathrm{df}=2$, $\mathrm{p}<0.39$ ).

\subsection{Heavy Metal Contamination Levels}

Basing on the contamination factor, $\mathrm{Cu}$ contamination was low at the deeper layer of PTZB, PTZC and PTZE (Table 4). Very high contamination of $\mathrm{Cu}$ was observed in the bottom and middle layers at KTDZ and the top and middle layers at PTZE and PTZF respectively. The contamination factors for Co were generally higher than that of the other heavy metals studied ranging between 2.12 and 62.15. With the exception of upper layer at KTDZ and the bottom layer at PTZC that were moderately contaminated, the copper tailings and pyrite soils sampled from the different zones and depths were very highly contaminated. For nickel, very high contamination of top layer was only observed at PTZC while for middle layer, the contamination was also very high except at PTZA and PTZF. For the bottom layer contamination with nickel was very high at KTDZ, PTZA and PTZE; high at PTZB and PTZF and moderate at PTZC and PTZD.

Table 3. The mean values ( \pm SEM, $n=3)$ of available heavy metal concentrations for copper tailings and pyrite soils, from the different zones and depths for dry and wet seasons

\begin{tabular}{|c|c|c|c|c|c|c|c|c|}
\hline \multicolumn{9}{|c|}{ Available heavy (Melich 3 extractable) concentrations $(\mathrm{mg} / \mathrm{kg})$} \\
\hline \multirow{2}{*}{$\begin{array}{l}\text { Site/depth } \\
\text { KTDZ }\end{array}$} & \multicolumn{2}{|l|}{ Copper } & \multicolumn{2}{|l|}{ Cobalt } & \multicolumn{2}{|l|}{ Nickel } & \multicolumn{2}{|l|}{ Lead } \\
\hline & Dry & Wet & Dry & Wet & Dry & Wet & Dry & Wet \\
\hline $0-30$ & $28.16 \pm 9.72 b$ & $10.08 \pm 2.85 b$ & $18.61 \pm 5.56 b$ & $15.31 \pm 0.29 b$ & $9.75 \pm 1.05 \mathrm{c}$ & $8.66 \pm 0.48 \mathrm{c}$ & $1.78 \pm 0.39 \mathrm{a}$ & $0.84 \pm 0.14 b$ \\
\hline $30-60$ & $154.85 \pm 15.18 \mathrm{a}$ & $155.18 \pm 10.85 \mathrm{a}$ & $142.73 \pm 34.33 \mathrm{a}$ & $204.66 \pm 10.39 c$ & $24.20 \pm 3.64 \mathrm{ab}$ & $19.49 \pm 4.85 b$ & $1.57 \pm 0.10 \mathrm{ab}$ & $1.59 \pm 0.33 \mathrm{ab}$ \\
\hline $60-90$ & $152.13 \pm 49.21 \mathrm{a}$ & $171.97 \pm 10.07 \mathrm{a}$ & $200.28 \pm 49.21 \mathrm{c}$ & $193.54 \pm 53.39 c$ & $25.45 \pm 6.12 \mathrm{ab}$ & $26.54 \pm 8.92 \mathrm{a}$ & $1.29 \pm 0.28 \mathrm{ab}$ & $1.55 \pm 0.28 \mathrm{ab}$ \\
\hline \multicolumn{9}{|l|}{ PTZA } \\
\hline $0-30$ & $74.71 \pm 10.72 \mathrm{a}$ & $73.96 \pm 10.52 \mathrm{a}$ & $179.51 \pm 8.68 b$ & $66.73 \pm 5.92 d$ & $18.36 \pm 0.80 \mathrm{ab}$ & $7.89 \pm 1.18 \mathrm{c}$ & $2.54 \pm 0.56 b$ & $1.73 \pm 0.25 \mathrm{c}$ \\
\hline $30-60$ & $66.79 \pm 11.02 \mathrm{a}$ & $96.51 \pm 11.28 b$ & $158.78 \pm 21.07 \mathrm{ab}$ & $155.30 \pm 4.97 \mathrm{ab}$ & $16.58 \pm 0.51 \mathrm{a}$ & $20.27 \pm 1.72 b$ & $0.36 \pm 0.11 \mathrm{a}$ & $1.91 \pm 0.19 b c$ \\
\hline $60-90$ & $47.84 \pm 10.71 d$ & $35.12 \pm 12.81 \mathrm{a}$ & $131.12 \pm 7.23 \mathrm{a}$ & $95.73 \pm 4.74 \mathrm{c}$ & $12.01 \pm 2.45 \mathrm{~d}$ & $18.51 \pm 1.85 \mathrm{ab}$ & trace & $0.23 \pm 0.53 \mathrm{a}$ \\
\hline \multicolumn{9}{|l|}{ PTZB } \\
\hline $0-30$ & $90.75 \pm 14.96 b c$ & $50.95 \pm 15.20 \mathrm{a}$ & $146.59 \pm 10.29 b c$ & $88.45 \pm 3.47 \mathrm{a}$ & $21.68 \pm 2.92 b c$ & $7.44 \pm 1.89 \mathrm{~d}$ & $2.51 \pm 0.64 a$ & $2.01 \pm 0.29 \mathrm{a}$ \\
\hline $30-60$ & $64.48 \pm 13.78 \mathrm{ab}$ & $94.02 \pm 13.80 \mathrm{ac}$ & $91.09 \pm 13.78 \mathrm{a}$ & $123.83 \pm 7.95 \mathrm{ac}$ & $15.95 \pm 1.23 \mathrm{a}$ & $21.43 \pm 4.34 \mathrm{c}$ & $2.91 \pm 0.54 \mathrm{a}$ & $2.38 \pm 0.41 \mathrm{a}$ \\
\hline $60-90$ & $70.84 \pm 16.00 \mathrm{ab}$ & $71.18 \pm 10.98 \mathrm{~b}$ & $110.05 \pm 43.14 \mathrm{ab}$ & $171.71 \pm 10.98 \mathrm{c}$ & $13.93 \pm 3.87 \mathrm{a}$ & $17.56 \pm 3.95 \mathrm{ab}$ & $0.14 \pm 0.03 b$ & $0.16 \pm 0.05 b$ \\
\hline \multicolumn{9}{|l|}{ PTZC } \\
\hline $0-30$ & $32.11 \pm 8.71 \mathrm{c}$ & $20.59 \pm 6.85 c$ & $187.90 \pm 23.80 \mathrm{~b}$ & $131.82 \pm 12.64 \mathrm{e}$ & $33.04 \pm 5.65 \mathrm{a}$ & $17.73 \pm 4.61 d$ & $4.30 \pm 0.45 \mathrm{ab}$ & $2.15 \pm 0.55 \mathrm{~d}$ \\
\hline $30-60$ & $7.42 \pm 1.35 \mathrm{a}$ & $11.56 \pm 2.07 \mathrm{a}$ & $146.77 \pm 15.48 \mathrm{a}$ & $102.24 \pm 11.15 \mathrm{~d}$ & $19.91 \pm 6.06 \mathrm{a}$ & $43.48 \pm 9.97 \mathrm{c}$ & $4.85 \pm 0.82 \mathrm{a}$ & $3.05 \pm 0.78 \mathrm{bd}$ \\
\hline $60-90$ & $3.11 \pm 0.51 b$ & $2.94 \pm 0.85 \mathrm{~d}$ & $13.91 \pm 2.19 \mathrm{f}$ & $4.40 \pm 1.19 \mathrm{c}$ & $6.04 \pm 0.77 b$ & $8.33 \pm 0.24 b$ & $0.52 \pm 0.17 \mathrm{c}$ & $0.12 \pm 0.02 \mathrm{c}$ \\
\hline \multicolumn{9}{|l|}{ PTZD } \\
\hline $0-30$ & $39.42 \pm 9.10 \mathrm{~b}$ & $17.47 \pm 4.24 \mathrm{e}$ & $42.88 \pm 7.40 \mathrm{c}$ & $31.82 \pm 3.49 b$ & $20.97 \pm 2.83 a$ & $6.50 \pm 0.56 b$ & $0.29 \pm 0.09 b$ & $0.40 \pm 0.03 b$ \\
\hline $30-60$ & $23.27 \pm 2.06 \mathrm{a}$ & $10.19 \pm 3.17 \mathrm{~cd}$ & $84.07 \pm 15.43 \mathrm{a}$ & $91.37 \pm 10.72 \mathrm{a}$ & $22.32 \pm 2.86 a$ & $35.68 \pm 12.10 \mathrm{a}$ & $1.49 \pm 0.48 \mathrm{a}$ & $1.18 \pm 0.36 \mathrm{a}$ \\
\hline $60-90$ & $12.74 \pm 3.94 \mathrm{de}$ & $6.73 \pm 0.67 c$ & $47.20 \pm 12.34 b c$ & $39.67 \pm 9.11 b$ & $6.67 \pm 1.16 b$ & $8.54 \pm 1.27 b$ & trace & $0.19 \pm 0.05 b$ \\
\hline \multicolumn{9}{|l|}{ PTZE } \\
\hline $0-30$ & $42.63 \pm 18.49 a$ & $23.81 \pm 9 . .67 b c$ & $206.67 \pm 19.57 \mathrm{bc}$ & $60.95 \pm 27.68 d$ & $37.56 \pm 4.08 \mathrm{~b}$ & $27.04 \pm 8.35 \mathrm{c}$ & $0.56 \pm 0.04 \mathrm{a}$ & $0.43 \pm 0.03 c$ \\
\hline $30-60$ & $35.59 \pm 5.15 a$ & $33.39 \pm 7.89 \mathrm{ac}$ & $166.71 \pm 14.57 \mathrm{a}$ & $197.00 \pm 41.53 \mathrm{c}$ & $19.47 \pm 5.17 \mathrm{a}$ & $18.86 \pm 2.79 \mathrm{a}$ & trace & $0.17 \pm 0.05 b$ \\
\hline $60-90$ & $21.33 \pm 4.04 b$ & $16.25 \pm 4.93 b$ & $142.97 \pm 37.20 \mathrm{a}$ & $233.24 \pm 31.53 b$ & $16.04 \pm 5.99 \mathrm{a}$ & $16.08 \pm 3.08 \mathrm{a}$ & trace & trace \\
\hline \multicolumn{9}{|l|}{ PTZF } \\
\hline $0-30$ & $43.89 \pm 5.97 \mathrm{a}$ & $18.91 \pm 6.75 b c$ & $49.85 \pm 6.72 b$ & $29.15 \pm 14.72 b$ & $24.65 \pm 7.45 b$ & $12.99 \pm 0.91 \mathrm{e}$ & $0.83 \pm 0.06 \mathrm{a}$ & $0.80 \pm 0.17 \mathrm{a}$ \\
\hline $30-60$ & $38.72 \pm 5.94 \mathrm{a}$ & $36.59 \pm 7.48 \mathrm{ac}$ & $27.60 \pm 7.31 \mathrm{a}$ & $39.84 \pm 12.46 \mathrm{c}$ & $8.09 \pm 5.93 \mathrm{a}$ & $5.83 \pm 0.52 d$ & $0.93 \pm 0.14 \mathrm{a}$ & $1.17 \pm 0.34 \mathrm{a}$ \\
\hline $60-90$ & $17.59 \pm 9.48 b$ & $30.41 \pm 6.25 \mathrm{ab}$ & $17.80 \pm 7.87 \mathrm{~d}$ & $46.11 \pm 9.84 b$ & $10.97 \pm 2.36 \mathrm{ce}$ & $9.19 \pm 6.00 \mathrm{ac}$ & $1.32 \pm 0.08 \mathrm{a}$ & $0.73 \pm 0.13 \mathrm{a}$ \\
\hline \multicolumn{9}{|l|}{ UPZ } \\
\hline $0-30$ & $4.80 \pm 0.67$ & $5.14 \pm 2.23$ & $3.96 \pm 0.92$ & $3.65 \pm 0.47$ & $2.62 \pm 0.10$ & $2.43 \pm 0.02$ & $0.18 \pm 0.06$ & $0.26 \pm 0.09$ \\
\hline
\end{tabular}

Means with different letters within the columns for dry and wet season for a particular zone are significantly different; Tukey’s HSD test, (p <.05).

\subsection{Clustering of the Zones}

Results of cluster analysis (CA) of zones based on physico-chemical data for the entire depth studied are presented in Figure 2. Clustering fused the zones into two major clusters. Zones of the pyrite trail distributed along the main drainage channel of the pollutant and convergence area were fused together while PTZD and PTZF distributed along minor drainage channel of pollutants were fused with UPZ and KTDZ. Further clustering of these zones showed that UPZ was distinctively different from KTDZ, PTZD and PTZF. 
Table 4. Contamination factors of heavy metals at different depths for each zone

\begin{tabular}{|c|c|c|c|c|c|c|c|c|}
\hline Heavy metal & Depth (cm) & KTDZ & PTZA & PTZB & PTZC & PTZD & PTZE & PTZF \\
\hline \multirow{3}{*}{$\mathrm{Cu}$} & $0-30$ & 3.64 & 1.89 & 1.46 & 5.10 & 5.77 & 12.96 & 5.60 \\
\hline & $30-60$ & 29.53 & 4.12 & 1.76 & 1.81 & 3.19 & 3.70 & 6.22 \\
\hline & $60-90$ & 30.87 & 3.82 & 0.45 & 0.58 & 1.51 & 0.72 & 5.85 \\
\hline \multirow{3}{*}{ Co } & $0-30$ & 2.77 & 17.70 & 14.47 & 37.00 & 7.84 & 34.70 & 8.55 \\
\hline & $30-60$ & 40.21 & 25.36 & 38.22 & 28.82 & 20.31 & 62.15 & 9.62 \\
\hline & $60-90$ & 45.58 & 28.96 & 9.30 & 2.12 & 9.44 & 47.83 & 7.55 \\
\hline \multirow{3}{*}{$\mathrm{Ni}$} & $0-30$ & 1.62 & 2.38 & 3.00 & 6.96 & 1.44 & 6.88 & 1.15 \\
\hline & $30-60$ & 6.41 & 3.35 & 16.04 & 10.69 & 9.63 & 34.34 & 3.51 \\
\hline & $60-90$ & 7.62 & 8.87 & 3.15 & 1.42 & 2.23 & 15.08 & 4.44 \\
\hline \multirow{3}{*}{$\mathrm{Pb}$} & $0-30$ & 9.28 & 6.90 & 12.89 & 21.79 & 4.26 & 1.33 & 4.25 \\
\hline & $30-60$ & 7.97 & 4.13 & 5.13 & 6.36 & 0.96 & 1.02 & 5.08 \\
\hline & $60-90$ & 5.08 & 5.11 & 6.06 & 7.56 & 3.26 & 0.40 & 4.53 \\
\hline
\end{tabular}

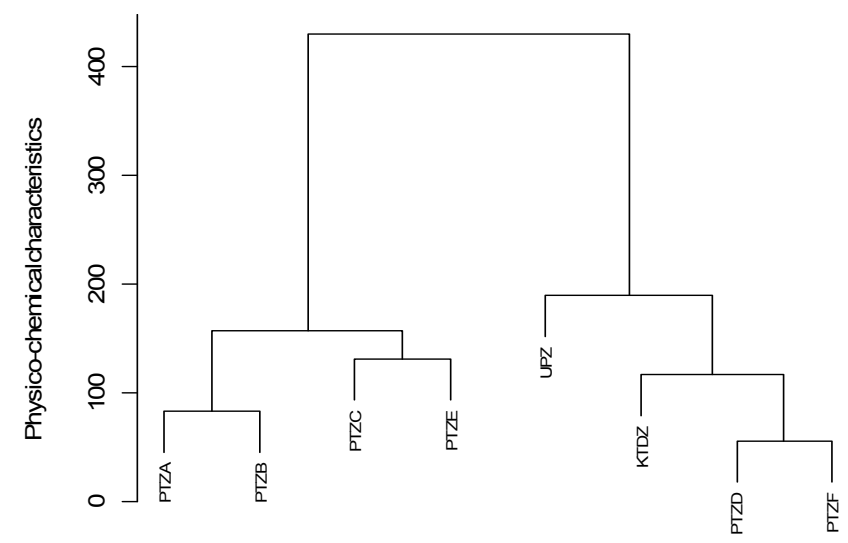

Fig 2. Dendrogram of physico-chemical characteristics for the Copper tailings and pyrite soils from the different zones.

\section{Discussion}

The results of this study revealed that $\mathrm{pH}$ of both copper tailings and pyrite soils was extremely low showing significant variation across zones, depths and seasons. The extremely low $\mathrm{pH}$ was due to the formation of acid mine drainage from the oxidation and weathering of sulfides $[16,17]$. The mean $\mathrm{pH}$ range determined in this study for both copper and pyrite soils respectively falls within the range characterized to be extremely acid [18] and associated with increased metal toxicities. The $\mathrm{pH}$ values recorded are in agreement with those determined for a site of comparable nature in the range of 2.8-4.8 [19] and those reported in earlier studies at the study site by [5] and [6]. The bottom layer at PTZF had mean $\mathrm{pH}$ values that were close to those of unpolluted soils. This can be attributed to sediments being shallow leading to the picking of the soil samples from the original unpolluted soil layer on which the sediments were deposited. Seedling establishment and growth of plants are fundamental to phytoremediation technology. They are unachievable at the observed $\mathrm{pH}$ levels of the copper tailings and pyrite soils. Thus, correction of $\mathrm{pH}$ of both copper tailings and pyrite soils to ranges of 5.5 to 7.0 or 5.5 to 6.5 at which most plants optimally grow or nutrients are most available to plants [19], is a prerequisite. This can be done through the application of either organic amendment or inorganic amendment materials such as compost, limestone and sewage.

It has been suggested that soils enriched in heavy metals may cause an accumulation of organic matter due to their toxicity to microbial populations and other soil biota [20,21]. However the current study revealed significantly lower organic matter content in the heavy metal polluted samples than in the unpolluted samples. This finding is in agreement with that of [22] who reported lower organic matter content in soils contaminated with heavy metals than the unpolluted. The top layer had significantly higher organic matter content than the middle and bottom layer at KTDZ. This is attributed to inflow of fresh waters from the nearby hills laden with organic materials. Organic matter is important for the retention of metals by soil solids, thus decreasing mobility and bioavailability [23]. Therefore organic matter enrichment of copper tailings and pyrite soils should be devised during their phytoremediation to promote the establishment and survival of the plant species used.

The study revealed a poor nutritional status of copper tailings and pyrite soils on the basis of available phosphorous and total nitrogen contents. This finding is in line with earlier findings of [24] and [25] who reported nutrient deficiency in mine soils. Similarly [26], also reported low nitrogen mineralization rates, low phosphate availability and low soil organic matter to be characteristic of such soils leading to poor nutrition status. This partly accounts for the continued absence of growth of plants in the area. The distribution of total nitrogen and available phosphorous was also heterogeneous with significant spatial distribution variation across zones and depth. In aided phytoremediation, amendment protocols should target reinstatement of nitrogen and phosphorous to levels conducive to the growth of plants through application of organic amendments.

The available concentration of heavy metals in copper tailings and pyrite soils most especially $\mathrm{Cu}, \mathrm{Co}$ and $\mathrm{Ni}$ were in most cases exceptionally higher than in the unpolluted soils. This finding is in agreement with that of [27], who found out that in unpolluted soils, the mobile fraction (available concentration) of heavy metals is small but tends 
to increase considerably in polluted soils and hence be hazardous to the ground water or food chain. Their contamination factor was in the range of high to very high contamination. This was due to the exposure of pyretic material (metal sulphide) to air and water leading to its oxidation and hydrolysis ultimately causing the acidification and solubilisation of heavy metals [28]. The low availability of heavy metals in unpolluted soils may be attributed to the usually lower total concentration as compared to the mine waste soils from which the available fractions are mobilised and the $\mathrm{pH}$ that was very close to neutrality at which low mobility of all heavy metals has been observed [23]. In the soil environment, sorption is the dominating speciation process and thus the largest fraction of heavy metal in a soil is associated with the solid phase of the soil [23]. Thus the significantly higher organic matter content of unpolluted soils could have further limited the available fractions of the heavy metals through sorption.

The distribution of available heavy metal concentrations was heterogeneous, with significant spatial variation across depth and zones. Heavy metals are said to be more mobile under acidic conditions and low organic matter content, which were characteristic of both the copper tailings and pyrite soils. With higher mobility, there was higher downward migration of heavy metals to the lower layers during the wet season upon reception of heavy rainfall. At KTDZ the available heavy concentrations were found to be significantly lower in the top layer than in the subsequent lower layers. The inflow of fresh waters laden with unpolluted soils rich in organic matter from the slopes of the adjacent hills [29], had dilution and sorption effect on heavy metals respectively. On the other hand, the available concentrations of heavy metals in the top layer of most zones in the pyrite trail during the dry season had significantly higher concentrations than those of the top layer in the wet season. The migration to the top layer was driven by capillary rise and evaporation, leading to the crystallization of the salts of heavy metals.

All the physico-chemical characteristics studied were heterogeneously distributed and in the ranges that strongly impede the re-establishment of self sustaining plant cover (phytostabilisation) to limit further pollution. Thus, adjustment of these characteristics to homogeneously distributed conditions suitable for re-establishment of a permanent plant cover through amendment application is complex. It may require site specific amendment protocols to be designed for large to avoid the emergence of red spots with limited plant growth.

Cluster analysis of zones suggested that the pyrite zones distributed along the area that was drained by the main channel were more polluted than those distributed along the area that was drained by the minor channel. This may be attributed to the entire depth under study for the zones within the area that was drained by the main channel being composed of sediments of acidic pyrite materials that were highly polluted. The pyrite trail is basically sediment of acidic materials which may be one or more meters deep.

\section{Conclusions and Recommendations}

The copper tailings and pyrite soils were extremely acidic, deficient in nitrogen and available phosphorous; and heavily contaminated with heavy metals to levels that limit the re-establishment of plants. Due to the persistent nature of the pollutants, natural regeneration of the area in the foreseeable future is unlikely, thus a need for human intervention to avert the enduring pollution of the adjacent area through acid mine drainage and eolian dispersal during the wet and dry seasons respectively. The physico-chemical characteristics of copper tailings and pyrite soils were heterogeneously distributed making the application of amendments to re-instate homogenously distributed physico-chemical characteristics that are suitable for plant growth un attainable.

\section{Acknowledgement}

The authors are grateful Swedish International Development Agency (Sida) for the financial support extended through Makerere University. We also acknowledge the permission by the Uganda Wild life Authority (UWA) to conduct research in QECA. Finally, we are also grateful to Uganda National Council for Science and Technology (UNCST) for granting us permission to carry out this research. The authors wish to thank Professor Ingvar Backéus of Uppsala University, Sweden, for his comments on the paper before submission.

\section{References}

[1] R. Careillo-Gonzalez and M. C. A. Gonzalez-Chavez, "Metal accumulation in wild plants surrounding mining wastes", Environmental Pollution, 144, 84-92, 2006.

[2] S. Tandy, J. R. Healey, M. A. Nasson, J. C. Williamson, D. L. Lones "Remediation of metal polluted mine soil with compost: composting versus incorporation". Environmental pollution, 157, 690-697, 2009.

[3] M. Miransari, "Hyperaccumulators, arbuscular mycorrhizal fungi and stress of heavy metals", Biotechnol Adv, doi: 10.1016/J.biotechadv.2011.04.006, 2011.

[4] M. Capuana, "Heavy metals and woody plant-biotechnologies for phytoremediation", iForest 4:7-15. 2011

[5] H. Oryem-Origa, A. Makara and F. M Tusiime, "Propagule Establishment in the Acid-Mine Polluted Soils of the Pyrite Trail in Queen Elizabeth National Park, Uganda". African Journal of Ecology, 45, 84-90, 2007.

[6] A. Muwanga H. Oryem-Origa, A. Maksara, T. Hartwig, A. Ochan, M. Owor, D. Zachmann and W. Pohl, "Heavy Metals and Their Uptake by Plants in the River Nyamwamba-Rukoki-Kamulikwezi-Lake George System, Western Uganda", African Journal of Science and Technology, Science and Engineering Series, 10, 60-69, 2009. 
[7] P. J. C., Favas, J., Pratas, M.E.P., Gomes, and V. Cala, "Selective chemical extraction of heavy metals in tailings and soils contaminated by mining activity: Environmental implications". Journal of Geochemical Exploration, 111, $160-171,2011$.

[8] D. W. Nelson and L. E. Sommers, (1982). "Total carbon, organic carbon, and organic matter". In A. Miller, R. H. D. R. Keeney (Eds.), methods of soil analysis. Part 2. Chemical and microbiological Properties, 2nd Edition, Agronomy, 9, American Society of Agronomy, Madison, WI, pp 539-594, 1982.

[9] J. R. Okalebo, K. W. Gathua, and P. L. Woomer, "Laboratory methods of soil and plant analysis". A working manual. 2nd edition, Nairobi; Tropical Soil fertility and programme, 2002.

[10] J. M. Bremner and C. S. Mulvaney, "Nitrogen-Total." P. 595-624, In: A.L. Page et. al. (eds). Methods of soil analysis, Part 2, 2nd edition, Agronomy Monograph 9, 1982.

[11] Knudsen, D and Beegle, D, "Recommended Phosphorous tests" P. 12-15, In: Dahnke (ed.), Recommended Chemical Soil Tests Procedures for North central Region, Bulletin No. 499 (Revised), North Dakota Agric. Exp. Sta., Fargo, North Dakota, 1988.

[12] C. Savvides, A. Papadopoulos, K. J. Haralambous, and M. Loizidou, "Sea sediments contaminated with heavy metals: metal spéciation and removal," Wat. Sei. Tech., 32(9-10), 65-73, 1995.

[13] H. Pekey, D. Karakas, S. Ayberk, L. Tolun, and M. Bakoglu, "Ecological risk assessment using trace elements from surface sediments of Izmit Bay (Northeastern Marmara Sea) Turkey," Marine Pollution Bulletin, 48, 946-953, 2004.

[14] M. N. Samir, M. A. Okbah, S. M, Kasem, "E nvironmental assessment of heavy metal pollution in bottom sediments of Aden port, Yemen, International Journal of Oceans and Oceaonography, 1, 99-109, 2006.

[15] R Development Core Team, "R: A Language and Environment for Statistical Computing", R Foundation for Statistical Computing, Vienna. Available on: http://www.R-project.org/, 2011. Accessed on $13^{\text {th }} /$ August $/ 2013$.

[16] A. Alcolea, M. Vázquez, A. Caparrós, I. Ibarra, C. García, R. Linares, R. Rodríguez, "Heavy metal removal of intermittent acid mine drainage with an open limestone channel", Minerals Engineering, 26: 86-98, 2012.

[17] V. Asensio, F. A. Vega, M. L. Andrade and E. F. Covelo, "Technosols made of wastes to improve physico-chemical characteristics of a copper mine soil", Pedosphere, 23, 1-9, 2013.
[18] USDA, "Soil quality indicators: pH soil quality sheet.8", available on at www.statlab.lastatc.educ, 1998. Accessed $4^{\text {th }}$ April 2013

[19] L. Perry, "pH for garden", UVM Extension system. University of Vermont extension, Department of Plant and Soil Science, Available on: http://pss.uvm.edu/ppp/pubs/oh34.htm, 2003. Accessed on $20 \mathrm{th} / 05 / 2014$

[20] S. Suavé, M. B. McBride, W. A. Norvell, W. H. Hendershot, "Copper solubility and speciation of in situ contaminated soils: effects of copper level, $\mathrm{pH}$ and Organic Matter", Water Air Soil Pollut., 100,133-149, 1997.

[21] S. Suavé, "Copper inhibition of soil organic matter decomposition in a seventy year field exposure", Environ. Toxicol. Chem., 25, 854-857, 2006.

[22] T. D. Lamba, H. Minga, M. Megharaj, R. Naidua, "Heavy metal $(\mathrm{Cu}, \mathrm{Zn}, \mathrm{Cd}$ and $\mathrm{Pb})$ partitioning and bioaccessibility in uncontaminated and long-term contaminated soils", Journal of Harzadous Materials, 171, 1150-1158, 2009.

[23] T. Sherene, "Mobility and transport of heavy metals in polluted soil environment", Biological Forum-An Internation Journal, 2, 112-121, 2010.

[24] V. Asensio, F. A. Vega, L. Andrade and E. F. Cavelo (2011). "Tree vegetation to improve physico-chemical properties in bare mine soils" Fresenius Environmental Bulletin. 20: 3295-3303.

[25] O. Barrutia, U. Artetxe, A. Harnandez, J. M. Olano, J. I. Garcia-Plazaola, C. Garbisu and J. M. Becerril "Native plant communities in an abandoned $\mathrm{Pb}-\mathrm{Zn}$ mining area of northern Spain: Implications for phytoremediation and germoplasm preservation", International Journal of Phytoremediation, 13 , 256-270, 2011.

[26] J. A. King, "Some Physical Features of Soil after Opencast Mining", Soil Use Management, 4, 23-30, 1988.

[27] W. Friesl, E. Lombi, O. Horak and W.W. Wenzel. "Amendments to reduce trace elements mobility. In: Proceedings 6th International conference on the biogeochemistry of trace elements" Guelph, 2001.

[28] M. Simón, F. Martín, I. Ortiz I., I. García, J. Fernández, E. Fernández, C. Dorronsoro, J. Aguilar. "Soil pollution by oxidation of tailings from toxic spill of a pyrite mine" Science of the Total Environment, 279, 63-74, 2001.

[29] J. E. Ssenku, M. Ntale, I. Backéus, L. Kari, and H. Oryem-Origa, "Dynamics of plant species composition during phytostabilisation of copper mine tailings and pyrite soils, Western Uganda" Journal of Environmental Engineering and Ecological Science, Accepted manuscript. 